\title{
Kebijakan Penanggulangan Tindak Pidana Narkotika di Wilayah Maluku
}

\author{
Yonna Beatrix Salamor', Erwin Ubwarin ${ }^{2}$ \\ ${ }^{1}$ Program Studi Ilmu Hukum, Universitas Pattimura \\ Email: yonnahukum@gmail.com \\ ${ }^{2}$ Program Studi Ilmu Hukum, Universitas Pattimura \\ Email: eubwarin@gmail.com
}

\begin{abstract}
ABSTRAK
Upaya untuk menanggulangi semua bentuk kejahatan senantiasa terus diupayakan, kebijakan hukum pidana yang ditempuh selama ini tidak lain merupakan langkah yang terus digali dan dikaji agar upaya penanggulangan kejahatan tersebut mampu mengantisipasi secara maksimal tindak pidana yang secara faktual terus meningkat. Penggunaan hukum pidana sebagai sarana untuk melindungi masyarakat dari ancaman maupun gangguan kejahatan sebenarnya merupakan masalah politik kriminal yaitu usaha rasional untuk menanggulangi kejahatan.Kecenderungan penyalahgunaan dan peredaran narkotika setiap tahun mengalami peningkatan, hal ini telah menadi ancaman bahaya yang serius terhadap berbagai aspek kehidupan manusia, masyarakat dan bangsa. Penanggulangan tidak saja membutuhkan komitmen dan kesanggupan semua pihak, tetapi aksi nyata semua jajaran pemerintah, pihak legislatif baik pusat maupun di daerah dan partisipasi aktif seluruh lapisan masyarakat termasuk organisasi non pemerintah (NGO) serta dunia usaha. Tujuan penelitian untuk mengetahui bentuk penanggulangan tindak pidana narkotika di wilayah Maluku yang dilakukan baik oleh Pemerintah, aparat penegak hukum maupun partisipasi masyarakat Maluku memberantas peredaran narkotika. Dalam penelitian ini, metode yang digunakan adalah yuridis empiris, selain itu peneliti juga melakukan wawancara dan pengambilan data di instansi-instansi yang berkaitan dengan penelitian ini. Berdasarkan penelitian yang dilakukan, ditemukan jumlah pengguna narkoba di Propinsi Maluku sejak ahun 2015 sebanyak 27.940 jiwa. Maluku yang sebagian besar wilayah berupa lautan, peredaran narkotika $70 \%$ dilakukan melalui jalur laut. Oleh karena itu, penanggulangan tindak pidana narkotika di Maluku dilakukan dengan mengunakan sarana penal maupun non penal. Partisipasi masyarakat dalam penanggulangan tindak pidana sangat membantu demi pencegahan peredaran narkoba.
\end{abstract}

Kata kunci: kebijakan penanggulangan, narkotika, Maluku

\section{PENDAHULUAN}

Politik atau kebijakan hukum pidana pada dasarnya merupakan aktivitas yang menyangkut proses menentukan tujuan dan cara melaksanakan tujuan tersebut. Terkait proses pengambilan keputusan atau pemilihan melalui seleksi antara berbagai alternatif yang ada mengenai apa yang menjadi tujuan sistem hukum pidana mendatang.

Dengan demikian kebijakan hukum pidana berkaitan erat dengan proses penegakan hukum pidana secara menyeluruh. Oleh sebab itu, kebijakan hukum pidana diarahkan pada konkretisasi/operasionalisasi hukum pidana material (substansi), hukum pidana formal (hukum acara pidana) dan hukum pelaksana pidana. Selanjutnya kebijakan hukum pidana dapat dikaitkan dengan tindakan-tindakan:

1. Upaya pemerintah untuk menanggulangi kejahatan dengan hukum pidana

2. Merumuskan hukum pidana agar sesuai dengan kondisi masyarakat

3. Kebijakan pemerintah untuk mengatur masyarakat dengan hukum pidana

4. Menggunakan hukum pidana untuk mengatur masyarakat dalam rangka mencapai tujuan yang lebih besar.

Upaya untuk menanggulangi semua bentuk kejahatan senantiasa terus diupayakan, kebijakan hukum pidana yang ditempuh selama ini tidak lain merupakan langkah yang terus menerus digali dan dikaji agar upaya penanggulangan kejahatan tersebut mampu mengantisipasi secara maksimal tindak pidana yang secara faktual terus meningkat. 
Kebijakan penanggulangan kejahatan atau yang biasa dikenal dengan istilah politik criminal dapat meliputi ruang lingkup yang cukup luas. G. Peter Hoefnagels mengatakan upaya penanggulangan kejahatan dapat ditempuh dengan(Arief, 2001, h. 45):

1. Penerapan hukum pidana (criminal law application)

2. Pencegahan tanpa pidana (prevention without punishment)

3. Memengaruhi pandangan masyarakat mengenai kejahatan.

Dengan demikian, upaya penanggulangan kejahatan secara garis besar dapat dibagi menjadi dua, yaitu lewat jalur "penal" (hukum pidana) dan lewat jalun non hukum pidana (bukan/diluar hukum pidana). Upaya penanggulangan kejahatan lewat jalur penal lebih menitikberatkan pada sifat "repressive" (penindasan/pemberantasan/penumpasan), sesudah kejahatan terjadi, sedangkan jalur "non penal" lebih menitikberatkan pada sifat "preventif" (pencegahan/ penangkalan /pengendalian).

Kecenderungan penyalahgunaan dan peredaran narkotika setiap tahun mengalami peningkatan, hal ini telah menjadi ancaman bahaya yang serius terhadap berbagai aspek kehidupan manusia, masyarakat dan bangsa. Penanggulangan tidak saja membutuhkan komitmen dan kesanggupan semua pihak, tetapi juga aksi nyata semua jajaran pemerintah, pihak legislatif baik pusat maupun di daerah dan partisipasi aktif seluruh lapisan masyarakat termasuk organisasi non pemerintah (NGO) serta dunia usaha.

Menurut data Badan Narkotika Nasional (BNN), situasi peredaran shabu (methamphetamine) selama 5 (lima) tahun terakhir (2007-2011) terus mengalami peningkatan, hal tersebut dapat digambarkan dengan bertambahnya jumlah kasus dan tersangka jenis shabu dengan peningkatan rata-rata sebesar $21,23 \%$ yaitu dari 5.456 kasus pada tahun 2007 menjadi 11.764 kasus pada tahun 2011, sedangkan tersangka mengalami peningkatan rata-rata sebesar $16,47 \%$ yaitu dari 8.651 tersangka pada tahun 2007 menjadi 15.683 tersangka pada tahun 2011 (Tim Ahli Badan Narkotika Nasional RI, 2014, h. 3). Hal ini menunjukkan bahwa jumlah penyalahgunaan narkotika terus meningkat secara fantastis. Bahkan apabila dihitung sejak tahun 1970-an hingga tahun 2012 atau selama 43 tahun sejak narkotika mulai menjadi candu di Indonesia, jumlah penggunanya telah meningkat sebanyak 200 kali lipat atau 20.000 persen.

Jika dulu pemakai atau pengguna narkotika identik dengan para pemuda dan pemudi berandalan yang berlatar belakang keluarga "broken home", sekarang pengguna narkotika lebih bervariasi. Bukan hanya pemuda dan pemudi, ada juga lansia, anak-anak, ibu rumah tangga, tokoh masyarakat, polisi, politisi, penggangguran, ahli hukum, dokter, pemuka agama, aktris dan sebagainya.

Kebanyakan pemakai narkotika hanya mengkonsumsi ganja, psikotropika atau paling tinggi morfin. Sekarang jenis narkotika sudah bertambah banyak seperti ekstasi, shabu, kokain, heroin (putaw). Kini bahkan ada heroin generasi baru dengan daya adikasi yang lebih kuat. Reaksinya lebih cepat serta lebih berat. Peningkatan jenis dan kualitas narkotika membuat dampak yang ditimbulkan semakin berbahaya.

Bukan saja di Ibu Kota Negara yang mempunyai peredaran Narkotika. Propinsi Maluku yang terdiri dari 11 Kabupaten/Kota merupakan wilayah kepulauan yang sangat stategis dalam arus pedagangan maupun pelayaran. Dengan wilayah yang sebagian besar terdiri atas lautan, menjadikan propinsi Maluku kaya akan berbagai sumber daya yang dapat dimanfaatkan. Selain itu, dengan wilayah yang sebagian besar lautan, untuk memperoleh akses perdagangan, 
digunakan melalui jalur udara dengan adanya 4 bandara udara yang terdiri dari 1 bandara udara internasional dan 3 bandara udara lokal. Untuk jalur laut, Maluku memiliki 13 pelabuhan laut. Meskipun demikian, masih saja ada beberapa pelabuhan laut yang belum tercover oleh Dinas Perhubungan Propinsi Maluku. Tidak diawasinya beberapa jalur pelabuhan laut oleh memungkinkan terjadinya berbagai tindak pidana, antara lain penyalahgunaan narkotika, penggelapan, ilegal logging dan lain-lain. Berbagai upaya telah dilakukan baik oleh pemerintah, aparat penegak hukum maupun partisipasi masyarakat guna menanggulangi peredaran narkoba di Maluku.

Berdasarkan fenomena yang telah dijelaskan diatas, maka permasalahan yang diangkat oleh penulis untuk dibahas adalah "Kebijakan Penanggulangan Tindak Pidana Narkotika di Maluku".

\section{METODE PENELITIAN}

Metode Penelitian adalah tata cara bagaimana suatu penelitian akan dilaksanakan. Mengingat penelitian ini merupakan penelitian hukum, maka metode penelitian yang digunakan adalah metode penelitian hukum. Penelitian hukum merupakan proses untuk menemukan aturan hukum, prinsip-prinsip hukum maupun doktrin-doktrim hukum untuk menjawab isu-isu hukum yang dihadapi(Marzuki, 2007, h. 35). Untuk menunjang penelitian ini maka penulis mempergunakan metode penelitian:

1. Jenis Penelitian

Penelitian tentang Kebijakan Penanggulangan Tindak Pidana Narkotika di Maluku adalah penelitian Yuridis Empiris. Penelitian Yuridis Empiris adalah suatu metode penelitian hukum yang berfungsi untuk melihat hukum dalam artian nyata dan meneliti bagaimana bekerjanya hukum di lingkungan masyarakat. Dikarenakan dalam penelitian ini meneliti orang dalam hubungan hidup di masyarakat maka metode penelitian hukum empiris dapat dikatakan sebagai penelitian hukum sosiologis. Dapat dikatakan bahwa penelitian hukum yang diambil dari fakta-fakta yang ada di dalam suatu masyarakat, badan hukum atau badan pemerintah.

2. Tipe Penelitian

Adapun tipe penelitian yang digunakan adalah deskriptif analitis yaitu memberikan gambaran terhadap objek yang diteliti melalui data atau sampel dan diolah atau dianalisis untuk diambil kesimpulannya (Sugiyono, 2009, h. 29).

3. Lokasi Penelitian

Dalam penelitian ini, lokasi yang digunakan sebagai lokasi penelitian adalah Provinsi Maluku. Provinsi Maluku terdiri dari 11 Kabupaten/Kota. Oleh karena itu yang dipilih sebagai lokasi penelitian adalah Kota Ambon. Kabupaten Maluku Tengah, dan Kabupaten Maluku Tenggara Barat.

4. Sumber Data

Dalam penelitian ini, jenis data yang digunakan adalah data primer yang dihasilkan dari penelitian lapangan yang diperoleh langsung dari responden penelitian yang terkait dengan tindak pidana narkotika. Dengan mengadakan studi/penelitian kepustakaan akan memperoleh data awal untuk dipergunakan dalam penelitian lapangan, dan data sekunder yang diperoleh dari penelitian kepustakaan terdiri dari:

1. Bahan Hukum Primer, berkaitan dengan masalah yang akan diteliti seperti UndangUndang Nomor 35 Tahun 2009 tentang Narkotika

2. Bahan Hukum Sekunder, merupakan bahan hukum yang memberikan penjelasan dan petunjuk mengenai bahan hukum primer seperti buku-buku referensi, jurnal hukum dan hasil-hasil penelitian karya ilmiah yang relevan dengan penelitian ini. 
3. Bahan Hukum Tertier, sebagai bahan hukum penunjang yang mencakup petunjukpetunjuk maupun penjelasan terhadap bahan hukum primer dan sekunder yaitu berupa kamus, ensiklopedia.

5. Teknik Pengumpulan Data

Pengumpulan data yang penulis lakukan dengan dua cara yaitu:

1. Penelitian Kepustakaan, yaitu pengumpulan data sekunder baik berupa peraturan perundang-undangan yang berlaku dan dokumen yang berkaitan dengan objek yang diteliti maupun teori-teori dan asas-asas hukum yang berkaitan dengan materi penelitian.

2. Penelitian Lapangan, yaitu pengumpulan data secara langsung dari pihak-pihak terkait dengan tindak pidana narkotika agar memperoleh dan menghimpun data primer atau data yang relevan dengan objek yang akan diteliti.

6. Teknik Analisa Data

Data penelitian diolah dan dianalisis secara kualitatif yaitu menganalisa data berdasarkan kualitasnya lalu dideskripsikan dengan menggunakan kata-kata sehingga diperoleh bahasan atau paparan dalam bentuk kalimat yang sistematis dan dapat dimengerti, kemudian ditarik kesimpulan.

\section{HASIL DAN PEMBAHASAN}

\section{Gambaran umum Peredaran Narkotika di Propinsi Maluku}

Narkotika merupakan zat atau obat yang sangat bermanfaat dan diperlukan untuk pengobatan penyakit tertentu. Namun, jika disalahgunakan atau digunakan tidak sesuai dengan standar pengobatan dapat menimbulkan akibat yang sangat merugikan bagi perseorangan atau masyarakat khususnya generasi muda. Hal ini akan lebih merugikan jika disertai penyalahgunaan dan peredaran gelap narkotika yang dapat mengakibatkan bahaya yang lebih besar bagi kehidupan dan nilai-nilai budaya bangsa yang pada akhirnya akan dapat melemahkan ketahanan nasional.

Maluku sebagai propinsi yang sebagian besar wilayahnya merupakan lautan dan daratan yang terdiri dari berbagai pulau besar dan kecil memungkinkan peredaran narkotika dapat dilakukan dengan leluasa. Kota ambon merupakan pintu masuk bagi para pengedar untuk mengedarkan narkoba.Jenis narkoba yang masuk di Maluku antara lain ganja, sabu-sabu, dan beberapa jenis narkoba lainnya. Selain itu, letak Maluku yang berbatasan dengan beberapa negara seperti Australia, Timor Leste dan Papua Nugini memberikan dampak tingginya kerawanan kejahatan narkoba. Jaringan sindikat bereaksi dengan memasarkan narkoba melalui beragam produk makanan, kue, parfum, suplemen, dan lainnya.

Karena sebagian besar wilayah Maluku yang terdiri dari laut, peredaran narkoba dapat dilakukan melalui udara (Bandar udara) maupun laut (pelabuhan). Data BNN Maluku memaparkan 70 \% peredaran narkoba di Maluku dilakukan melalui jalur laut, dan 30\% melalui jalur udara.Pengawasan terhadap pelabuhan sebagai jalur laut oleh aparat penegak hukum maupun bea cukai Maluku masih jauh dari yang diharapkan. Pada Tahun 2015 Maluku menduduki urutan ke7 dari 33 propinsi di Indonesia untuk peredaran narkoba dengan jumlah pemakai 27.940 jiwa dari jumlah populasi 1.168.800 jiwa yang sebagian besar ada di Kota Ambon.

Para pemakai narkoba dapat digolongkan menjadi beberapa golongan yaitu:

a. Coba Pakai, adalah mereka yang memakai narkoba kurang atau sama dengan 5 (lima) kali setahun. Jumlah pengguna narkoba dalam golongan ini berjumlah 10.474 jiwa $(0.88 \%)$ di Maluku. 
b. Teratur Pakai, adalah mereka yang memakai narkoba antara 6-49 kali dalam setahun. Pengguna narkoba golongan ini 8.151 jiwa (0.68\%) di Maluku.

Umumnya pemakai narkoba di Maluku berusia 14-20 tahun dengan jenis narkoba yang digunakan antara lain ganja, sabu-sabu. Generasi muda yang memakai narkoba dilatarbelakangi oleh beberapa faktor antara lain rasa ingin tau yang besar sehingga muncul sikap ingin cobacoba, pergaulan tanpa pengawasan orang tua. Dalam tahun 2016, ada 350 orang di kota Ambon yang menjalani proses rehabilitasi pada RSUD dr Haulussy Ambon dan BNN Maluku.

\section{Penanggulangan Tindak Pidana Narkotika di Maluku}

Maraknya narkoba di negeri ini, mulai dari penyalahgunaan sampai pengedaran dan penyelundupan dari segala penjuru lewat bandara dan pelabuhan laut. Penyalahgunaan narkoba menyentuh setiap lapisan masyarakat. Para pejabat bahkan ibu rumah tangga tidak terluput dari jeratan narkoba.

Keprihatinan yang lebih mendalam bahwa anak-anak digunakan sebagai sasaran pemasaran (kurir) maupun pengguna narkoba. Lalu lintas perdagangan gelap narkotika merupakan tindak kejahatan internasional, yang penanggulangannya memerlukan perhatian mendesak serta prioritas tinggi. Kejahatan ini sangat berkaitan dengan berbagai hal dan terorganisasi, sehingga dapat berpengaruh dan merusak perekonomian serta mengancam kestabilan keamanan dan kedaulatan negara.

Semua lapisan masyarakat sangat berkeinginan untuk menghilangkan perbuatan penyalahgunaan narkoba, karena selain merusak akhlak dan moral bangsa, kejahatan narkotika juga telah mengeruk keuntungan yang tidak sedikit dari hasil peredaran gelapnya bahkan telah menyedot keuangan masyarakat.

Narkotika disatu sisi merupakan obat atau bahan yang bermanfaat dibidang kesehatan atau pelayanan kesehatan dan pengembangan ilmu pengetahuan, sedangkan di sisi lain dapat menimbulkan ketergantungan yang sangat merugikan apabila dipergunakan tanpa pengendalian dan pengawasan yang ketat dan seksama. Penyalahgunaan narkoba merupakan masalah perilaku sosial, sehingga perlu pemberian informasi atau pengetahuan yang benar untuk setiap lapisan masyarakat khususnya generasi muda sehingga dapat mengubah perilaku dan pola pikir serta dapat membentuk karakter yang bermartabat.

Pemberantasan lalu lintas gelap narkotika ini merupakan tanggung jawab bersama setiap komponen baik pemerintah maupun masyarakat. Peningkatan, pengendalian dan pengawasan yang dilakukan oleh setiap komponen masyarakat sebagai upaya untuk mencegah dan memberantas penyalahgunaan dan peredaran narkotika sangat diperlukan karena kejahatan narkotika pada umumnya tidak dilakukan oleh perorangan secara berdiri sendiri, melainkan dilkaukan secara bersama-sama bahkan dilakukan oleh sindikat yang terorganisasi secara mantap, rapi dan sangat rahasia.

Penyalahgunaan narkotika di kalangan generasi muda termasuk di Maluku disebabkan oleh beberapa faktor pendorong, antara lain (Setiawan, 2015, h. 125):

1. Fisik: mencari kesenangan dan kegembiraan, mencari inspirasi, melarikan diri dari kenyataan atau semacam protes, rasa ingin tahu, meniru, coba-coba dan lain sebagainya. 
2. Sosial cultural (psikis dan psikologi): rasa setia kawan (solidaritas), merasa kuat dan berani, gagah-gagahan, tersedia dengan mudah terutama sekali peredaran yang illegal (kecuali di apotik yang pembeliannya dilengkapi dengan surat keterangan dokter atau resep).

3. Medis : seseorang yang dalam perkembangan jiwanya mengalami gangguan (stress, depresi dan frustasi) akan lebih gampang melarikan diri pada penyalahgunaan narkotika, yaitu untuk menghilangkan rasa malu, rasa segan, rendah diri dan kecemasan.

Penanggulangan tindak pidana narkotika di Kota Ambon memakai sarana pendekatan penal (hukum pidana) maupun non penal. Pendekatan Penal terdiri dari beberapa bagian, antara lain:

1. Substansi

Substansi terkait dengan peraturan perundang-undangan yang tersedia sesuai dengan tindak pidana. Indonesia telah memiliki Undang-Undang Narkotika yaitu Undang-Undang Nomor 35 Tahun 2009 tentang Narkotika.

Terkait dengan penanggulangan tindak pidana narkotika di Maluku, baik untuk produsen, Bandar maupun pengedar, diproses sesuai dengan hukum yang berlaku dimana keberadaan UU No. 35 Tahun 2009 sangat mengakomodir pemberian pidana bagi para produsen, Bandar maupun pengedar. Berdasarkan hasil penelitian, meskipun ancaman pidana yang berat pada tahapan putusan pengadilan, tetapi belum jua memberikan efek jera bagi beberapa bandar dan pengedar narkoba di Maluku.

2. Struktur

Bagian ini lebih mengedepankan struktur aparat penegak hukum. Dalam tindak pidana narkotika, bukan hanya pihak kepolisian namun juga anggota Badan Narkotika Nasional dan para pegawai Bea dan Cukai.

Di Maluku, pengawasan terhadap jalur perhubungan laut mendapat perhatian yang lebih serius. Dalam beberapa temuan, narkoba dikirim melalui jasa pengiriman barang, yang tidak hanya memakai jalur udara tetapi juga memakai jalur laut untuk diedarkan di daerah/ pulau yang tidak memiliki bandara udara mengingat wilayah Maluku yang sebagian besar terdiri dari pulau-pulau dan laut. Umumnya narkoba disalurkan melalui pelabuhan-pelabuhan kecil yang jarang mendapat perhatian dari aparat kepolisian maupun petugas bea cukai.

Masalah kekurangan anggota dalam upaya penanggulangan tindak pidana narkotika serta kurangnya prasarana penunjang dalam melaksanakan fungsi pengawasan di wilayah kepulauan Maluku merupakan kendala yang dihadapi aparat penegak hukum dalam pencegahan dan pengawasan terhadap peredaran narkoba di jalur laut.

3. Budaya

Di Maluku, khususnya di desa-desa yang jauh dari kota, masih menganggap pemberantasan narkoba sebagai hal yang tabu karena sebagian masyarakat desa tersebut masih menganggap peredaran narkoba tidak akan menjangkau wilayah atau daerah mereka. Oleh karena itu, BNN Maluku bersama Kepolisian setempat melakukan berbagai advokasi tentang penyalahgunaan narkotika dan bahaya narkoba bagi generasi muda. Kegiatan advokasi yang dilakukan melibatkan berbagai elemen masyarakat. Mulai dari tokoh masyarakat, tokoh adat, pemuda bahkan para ibu rumah tangga.

Dengan pengetahuan akan bahaya narkoba, diharapkan angka pengguna narkoba dari kalangan generasi muda akan berkurang. Tren terbaru khususnya di kota Ambon, sebagian besar pemakai narkoba adalah anak remaja perempuan usia sekolah baik SMP maupun SMA dengan latar belakang keluarga yang mampu.Keadaan keluarga "broken home" bukan lagi menjadi faktor dominan pengguna narkoba.

Untuk sarana non penal, penanggulangan tindak pidana narkotika dilakukan dengan pendekatan advokasi bagi para tokoh adat yang ada di setiap negeri di Maluku. Respon yang baik dari para 
tokoh adat dalam penanggulangan tindak pidana narkotika serta komitmen untuk memberantas peredaran narkoba sebagai bentuk partisipasi masyarakat, memberikan hasil yang cukup signifikan. Para tokoh adat bekerja sama dengan tokoh pemuda bahkan pemuda-pemudi di negeri mereka dalam beberapa pertemuan yang rutin dilakukan untuk mengevaluasi program penanggulangan narkotika di negeri masing-masing.

Selain itu juga, dari akademisi hukum rutin melakukan kegiatan sosialisasi dan edukasi kepada masyarakat khususnya siswa-siswi baik SMP maupun SMA yang ada di kota ambon, maupun di 10 kabupaten/kota yang ada di Maluku sebagai bentuk komitmen para akademisi untuk pencegahan peredaran narkoba bagi generasi muda Maluku.

\section{KESIMPULAN}

Berdasarkan uraian yang dilakukan, maka dapat disimpulkan kebijakan penanggulangan tindak pidana narkotika di Maluku dilakukan dengan menggunakan sarana penal (pidana) maupun non penal. Penggunaan sarana penal meliputi penjatuhan pidana yang berat bagi para pengedar maupun produsen yang tertangkap mengedarkan dan membuat narkotika di Maluku. Dari segi aparat penegakan hukum, tidak hanya menjadi tugas kepolisian semata, tetapi kerjasama dari Polisi, Para pegawai Bea Cukai, dan BNN dalam penanggulangan narkotika di Maluku terus terjalin. Masyarakat juga dilibatkan dalam penanggulangan kejahatan melalui kegiatan advokasi yang dilakukan oleh BNN maupun kepolisian khususnya di desa-desa yang jauh dari kota.

Untuk sarana non penal dilakukan melalui pedekatan seperti advokasi kepada para tokoh adat di setiap negeri adat di Maluku, juga edukasi dan sosialisasi oleh akademisi hukum tentang bahaya narkoba kepada generasi muda sekaligus sebagai bagian dari pengabdian kepada masyarakat.

Dalam usaha penanggulangan tindak pidana narkotika di Maluku terhadap kendala-kendala yang menghambat seperti kurangnya aparat penegak hukum untuk melakukan tindakan preventif maupun represif, keterbatasan sarana dan prasarana penunjang tugas aparat penegak hukum serta masih tertutupnya beberapa masyarakat terhadap advokasi penyalahgunaan narkoba.

\section{REFERENSI}

Arief, B. N. (2011). Bunga Rampai Kebijakan Hukum Pidana. Jakarta: PT. Kencana Prenada Media Group.

Arief, B. N. (2001). Masalah Penegakan Hukum dan Kebijakan Penanggulangan Kejahatan. Bandung: PT. Citra Aditya Bakti.

Marzuki, P. M. (2007). Penelitian Hukum. Jakarta: PT. Kencana Prenada Media Group.

Sasangka, H. (2003). Narkotika dan Psikotropika Dalam Hukum Pidana. Bandung: PT. Mandar Maju.

Setiawan, M. (2015). Karakteristik Kriminalitas Anak \& Remaja (Dalam Perspektif Pendidikan, Juvenile Delinquency, Narkotika, Hukum, Hak Anak, Agama, dan Moral). Jawa Barat: Ghalia Indonesia.

Sugiyono (2009). Metode Penelitian Kuantitatif, Kualitatif dan R\&D. Bandung : PT. Alfabeta.

Tim Ahli Badan Narkotika Nasional RI;. (2014). Pencegahan Penyalahgunaan Narkotika Bagi Masyarakat. Jakarta: BNN Publisher. 